\title{
Information technology as a facilitator of suppliers' collaborative communication, network governance and relationship longevity in supply chains
}

\author{
Author: \\ Richard Chinomona ${ }^{1}$ \\ Affiliation: \\ ${ }^{1}$ Department of Logistics, \\ Vaal University of \\ Technology, South Africa \\ Correspondence to: \\ Richard Chinomona \\ Email: \\ rchinos@hotmail.com \\ Postal address: \\ Department of Logistics,Vaal \\ University of Technology, \\ Private Bag X021, \\ Vanderbijlpark 1900, \\ South Africa \\ Dates: \\ Received: 03 Dec. 2013 \\ Accepted: 03 June 2013 \\ Published: 21 Aug. 2013 \\ How to cite this article: \\ Chinomona, R., 2013, \\ 'Information technology \\ resource as a facilitator \\ of suppliers' collaborative \\ communication, network \\ governance and relationship \\ longevity in supply chains', \\ Journal of Transport and \\ Supply Chain Management \\ 7(1), Art. \#83, 10 pages. \\ http://dx.doi.org/10.4102/ \\ jtscm.v7i1.83
}

\section{Copyright:}

(C) 2013. The Authors. Licensee: AOSIS OpenJournals. This work is licensed under the Creative Commons Attribution License.

Read online:
There is an increasing awareness about the paramount importance of information technology within business in the context of large businesses. However, research about the investigation of the role of information technology resources in fostering collaborative communication, network governance and relationship longevity in the small and medium enterprise sector has remained scant. The primary objective of this study was to investigate the influence of information technology on collaborative communication, network governance and relationship longevity in Zimbabwe's SME sector. Five research hypotheses were posited and sample data from 162 small and medium enterprise suppliers were collected and used to empirically test the hypotheses. The results of this study showed that information technology resources positively influenced small and medium enterprise suppliers' collaborative communication, network governance and consequential relationship longevity with their buyers in a significant way. Overall, the current study findings provided tentative support to the proposition that information technology resources, collaborative communication and network governance should be recognised as significant antecedents for improved relationship longevity between suppliers and their buyers in the SME setting. Therefore, managers in the small and medium enterprise sector and small and medium enterprise owners need to pay attention to both collaborative communication and network governance in order to optimise information technology resource impact on their relationship longevity with their business counterparts. Limitations and future research directions were also indicated.

\section{Introduction}

Managing supply chains with efficacy creates value and consequently enhances supply chain members' business performance (Zhao, Xie \& Zhang 2002). As indicated by Vijayasarathy (2004) and Prajogo and Olhager (2012), effective and efficient supply chain management (SCM) forms the basis upon which long-term, sustainable, competitive edge and superior supply chain performance contracts can be achieved. Supply chain contracts have increasingly become long term in nature and partners willingly share information regarding their processes, quality performance and even cost structure in order to achieve this objective (Helper \& Sako 1995; White, Daniel \& Mohdzain 2005; Lee, Kwon \& Severance 2007). Through close long-term relationships, the suppliers have become part of a well-managed chain resulting to lasting effect on the superior competitiveness and performance of the entire supply chain (Choi \& Hartley 1996; Kotabe Martin \& Domoto 2003; Vijayasarathy 2004).

A key question that can be asked is: What relationship-specific factors are likely to affect the development of long-term orientation in order for supply chain partners to realise the superior performance? It is worth noting that supplier communication and supplier network structure are two key constructs in the evolving paradigm of SCM - a paradigm whose general theme is the shifting of emphasis from isolated individual firm performance to superior long-term collaborative value creation in a whole supply chain. Supplier communication can be characterised as frequent, genuine and involving information sharing or personal contacts between supply chain partners in order to jointly find solutions or facilitate business (Holmen \& Pedersen 2010; Paulraj, Lado \& Chen 2008; Carr \& Pearson 1999). In the context of SCM, network structure refers to a grouping of businesses and customers who are characterised by strong linkages between supply chain members with low levels of vertical integration (Prajogo \& Olhager 2012). Researchers and managers have increasingly recognised that in order to capture potential synergy and create superior value in supply chains, the supply partners must develop effective communication and network structures (Aviv 2001; Su \& Zhang 2006). Consequently, research interest in supply chain collaborative communication and network governance is currently quite substantial and growing (Chen \& Paulraj 2004; Kim \& Mahoney 2006; Vijayasarathy 2004; Prajogo \& Olhager 2012). 
Recently, some researchers such as Paulraj, Lado and Chen (2008) have been particularly interested in identifying the key drivers of supplier communication and network structure; information technology (IT) has been singled out as a paramount driver in the relatively large body of models and empirical findings in the IT and management-related literature. It is recognised in the literature that more than ever before, today's information technology is permeating the supply chain at every point, transforming the way in which exchange-related activities are performed and the nature of the linkages between them (Rapp, Rapp \& Schillewaert 2008; Kim \& Jae 2007). A more recent perspective on linkages within the supply chain considers the role of inter-business communication systems, which are sophisticated information systems connecting separate supply chain partners (Lai, Wong \& Cheng 2010; Rapp, Rapp \& Schillewaert 2008; Trainor et al. 2011). The strength of inter-business IT systems has been particularly crucial with respect to enabling the process transformation needed to create effective networks (Brady, Saren \& Tzokas 2002; Brodie et al. 2007; Christiaanse \& Kumar 2000). Information technology also enhances supply chain efficiency by providing real-time information regarding product availability, inventory level, shipment status and production requirements (Kim \& Jae 2007; Kim \& Mahoney 2006). It has a vast potential to facilitate collaborative planning among supply chain partners by sharing information on demand forecasts and production schedules that dictate supply chain activities (Roseira, Brito \& Henneberg 2010; Trainor et al. 2011).

Despite the appreciation of the value of IT, supply communication, network structure and long term relationships traced in the literature, there is a relative dearth of studies that have specifically investigated the influence of IT use on relationship longevity and the mediating role of collaborative communication and network governance. Furthermore, most of the studies that have attempted to investigate the relationships between some of these variables have been conducted in the developed countries of Europe and the USA (Holmen \& Pedersen 2010; Paulraj et al. 2008), or the newly developed countries of Asia (Choi \& Wu 2009). Therefore, researches that has investigated the relationships between IT utilisation, supplier collaborative communication, network governance and relationships longevity in supply chains in the context of the developing countries of Africa remains scant - hence the need for the current empirical study.

Based on these identified research gaps, this article has three objectives:

- To examine the causal influence of information technology on a supplier's relationship longevity in Zimbabwe's supply chains.

- To present an empirical investigation into the mediating role of supplier collaborative communication and network governance in IT - relationship longevity linkage.

- To apply the Network theory in this research context.

This study has a strong theoretical grounding from the current research. On the whole, the findings of this study are expected to contribute new knowledge to the existing body of SCM literature in addition to providing practical implications to supply chain practitioners within the context of a developing African country such as Zimbabwe.

The remainder of this article will review the literature on Network theory, then propose a conceptual research model and develop the research hypotheses. The study will also provide the research methodology, data analysis and results. The results are then discussed, implications provided and limitations and future research directions highlighted.

\section{Literature review}

This section of the article will provide a review of literature on Network analysis theory, information technology resources, collaborative communication, network governance and relationship longevity.

\section{Network analysis theory}

The network concept, which can be traced by its roots from anthropology and sociology (Streeter \& Gillespie 1992), has recently become a standard technique for studying the structure of social networks (Ma, Yao \& Xi 2009). In the business arena, network analysis is methodologically becoming an increasingly popular tool that is used to understand complex patterns of interaction (Dyer \& Nobeoka 2000; Holmen \& Pedersen 2010). By definition, network analysis examines actors that are connected directly or indirectly by one or more different relationships, whilst a network refers to any bounded set of connected social units (Paulraj et al. 2008). In a network analysis four issues are important to note:

- Networks have boundaries and some criteria exist that determine membership in the network.

- Networks are also presumed to be embedded in larger social systems, therefore it is sometimes difficult to distinguish between a network and its broader social context.

- Relational properties focus on the content of the relationship between network members and on the form of these relationships. According to Choi and Kim (2008), transaction content and the nature of relationships - the two aspects of relational properties - seek to understand why a network exists and try to ascertain the functions performed by the relations among the members. Whilst transaction content denotes what flows or what is exchanged in networks (e.g., resources, information, influence and social support), the nature of relationships refers to the qualities inherent in the relationship between members of the network.

- Structural properties describe the way in which members fit together to form social networks as individual members, subgroups and total networks. Measures of individual members describe the differences among their connections to other members of the network, whilst measures of subgroups as the unit of analysis represent the structural characteristics of clusters within the total network. According to Chen and Paulraj (2004), the advances in computer technology have made it possible to design network studies and conduct complex network analyses, which were impossible just a decade ago. 
By relating Network analysis theory to the current study, this research accordingly submits that IT is an important resource that characterises both the nature of relationships and structure of supply chain networks. As such, it can be used as a tool to understand the nature of supply chain network structures and the depth and content of communication in supply chains. Eventually, the depth of communication and the strength of network structure influences the longevity of business relationships in supply chains and hence business performance.

\section{Supplier information technology use}

Information technology is referred to as the knowledge process and its application of methods, processing, transferring and making information improvement (Oz 2005). IT includes gathering, organising, storing, publishing and using the information in the form of sound, picture graphics, text and number by using a computer and telecommunication tools (Crowston \& Myers 2004). According to Ali and Kumar (2011), IT provides several advantages for industry: increasing the rate of operation speed; providing the stability and compatibility in order to create data; promoting efficiency for the organisation; improving productivity; and controlling internal processes. As a business resource, IT can reduce transactional costs by electronic data transaction and shared databases and removes intermediaries in organisational processes (Fisher 2000; Zhou, Yim \& Tse 2005). Accordingly, the ability of a company to exploit the benefits emanating from IT resource utilisation will equip it with a competitive advantage over its competitors (Melville, Kraemer \& Gurbaxani 2004). Therefore, using information technology represents a business's capability in recognising and adapting to emerging technologies (Ali \& Kumar 2011). In today's business world, it has become imperative for supply chain members to invest more in IT and foster a commitment to the application of new technology within their supply chains (Christiaanse \& Kumar 2000; Oz 2005). In this study, IT use is defined as the presence and utilisation of electronic transactions and communication in various forms between the supply chain partners (Zhou et al. 2005).

\section{Supplier collaborative communication}

The importance of communication and information sharing has been heavily emphasised for effective inter-organisational relationships in the developed countries such as the United States of America (Monczka et al., 1998; Mohr \& Nevin 1990). According to Prahinski and Benton (2004), collaborative communication can be regarded as the glue that holds together a channel of distribution or supply chains and it is a necessity for successful supplier relationship (Monczka, Tren \& Handfield 2002; Galt \& Dale 1991; Krause 1999). Communication theory indicates that communication can be viewed as a transmission process through a channel (mode) and that collaborative communication has four important facets characterised in terms of frequency of communication, the direction (whether bi-directional or unidirectional), content (whether direct or indirect) and modality (whether formal or informal) (Paulraj et al. 2008; Holland, Lockett \&
Blackman 1994). In supply chain management, collaborative communication can be expected to be frequent, genuine and involving personal contacts between buying and selling personnel. Hitherto, SCM literature has found that many supplier product problems have been due to poor communication (Chen \& Paulraj 2004; Holland 1995). In the current study, supplier communication is collaborative and refers to a communication effort that emphasises indirect influence strategy, formality and feedback in unison (Prahinski \& Benton 2004).

\section{Supplier network governance}

In SCM, networks constitute an immediate form of governance characterised by task, authority and co-ordination mechanisms across distinct businesses that enhance supply chain performance (Dyer \& Nobeoka 2000; Harland \& Knight 2001). Roseira et al. (2010) asserted that the structure of a business's network and the location of each business and its contacts within the structure define the business's chances of obtaining benefits from the network. Such reasoning has been supported in the extant literature by Holmen and Pedersen (2010) and Lorentz and Ghauri (2010), who submitted that if a supply network structure provides many opportunities for businesses to benefit, then they are more likely to accept that they can all gain and to be motivated to co-operate rather than compete with each other. Thus, network structures establish some of the conditions that potentially affect the motivation of businesses to co-operate with each other (Cannon, Achrol \& Gundlach, 2000; Roseira et al. 2010). When networks are well developed, a kind of governance structure emerges (Ma et al. 2009). However, according to Chen and Paulraj (2004), the lower the levels of vertical integration, the stronger the linkages between the supply chain partners. Thus, effective supply network structures are personified by suppliers' interdependence (Paulraj et al. 2008). In line with existing research, supply network structure development is characterised by non-power based relationships and interbusiness co-ordination as well as the informal social systems that are linked through a network of relations (Dyer \& Nobeoka 2000; Harland \& Knight 2001; Lambert \& Cooper 2000; Croom 2001).

\section{Supplier relationship longevity}

Relationship longevity is often defined as both the actual length of the relationship as well as the expectation of continuing or a desire to continue the relationship (Kim 2001; Barkema \& Vermeulen 1997; Heide \& John 1990; Moorman, Zaltman \& Deshpande 1992). Supplier contracts have increasingly become long-term; more and more suppliers must provide customers with information regarding their processes, quality performance and even cost structure (Krause, Pagell \& Curkovic 2001; Helper 1991; Helper \& Sako 1995). Perhaps the reason for that, as indicated in the management literature, is that long-lasting relationships are profitable and beneficial. It is posited in the literature that the longer the business relationship is, the more co-operative, trusting and committed the companies will be through the adaptations they make (Choi \& Hartley 1996). Krause and 
Ellram (1997) found that maintenance of relationships over a longer period of time induces supply chain partners to be more willing to share risks and rewards, whilst Carr and Pearson (1999) suggested that companies would gain benefits by placing a larger volume of business with fewer suppliers using long-term contracts. Further buttressing the notion of Carr and Pearson (1999), Kotabe et al. (2003) discovered that strategically managed long-term relationships with key suppliers have a positive impact on business's supplier performance. Their argument was that through a long-term relationship, the supplier will become part of a well-managed chain and will have a lasting effect on the competitiveness of the entire supply chain (Krause et al. 2001). Following the suggestions of existing research, the theoretical construct is operationalised to involve the initiatives taken by the buying business to encourage long-term relationships with their suppliers (Kim \& Mahoney 2006).

\section{Conceptual model and hypothesis development}

Drawing from the network theory, the literature of SCM and logistics management aforementioned, a conceptual model has been developed as shown in Figure 1. The model consists of five constructs: one predictor - supplier information technology use; three mediators - supplier collaborative communication, supplier network structure development and supplier long-term relationship; and one outcome variable - supplier performance. Conceivably, the suppliers' information technology use influences their collaborative communication, network structure development and consequent relationship longevity in supply chains. Detailed explanations of the associations between these constructs are provided in the hypotheses developed hereafter.

\section{Supplier information technology use and collaborative communication}

Increasingly, resource has become a vital element in contemporary supply chain systems, transforming the way that exchange-related activities are performed (Kim \& Mahoney 2006; Palmer \& Griffith 1998). It is noted in the literature that IT can generate a sustainable competitive advantage by facilitating collaborative communication and fostering relational capabilities (Grover \& Malhotra 1997;

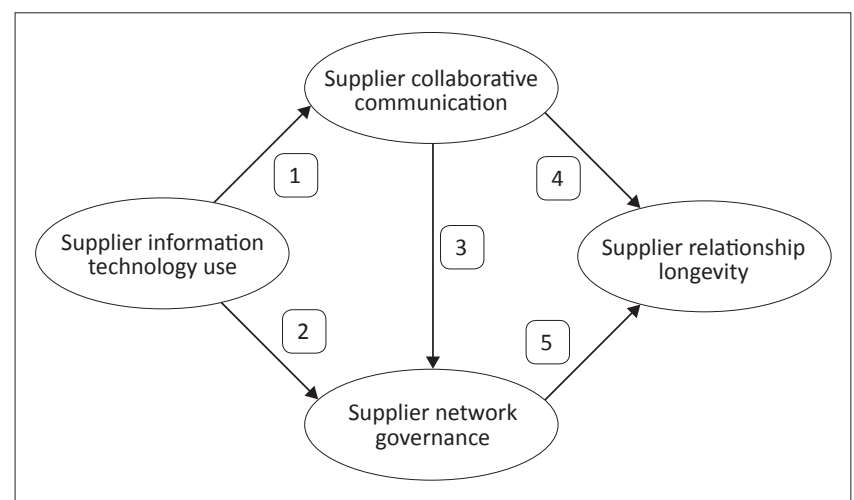

FIGURE 1: Conceptual model.
Walton and Marucheck 1997; Subramani 2004). Accordingly, sustainability of advantage is possible when IT resources facilitate collaborative communication, leading to the development of complementary capabilities (Powell \& DentMicallef 1997; Dyer \& Singh 1998; Kale, Singh \& Perlmutter 2000). In the context of this study, it is argued that IT as a crucial business resource connects and creates an enabling environment that fosters suppliers' communication with their business counterparts. Therefore, the ability of suppliers in Zimbabwe to aptly utilise IT resources to connect with their partners will likely generate a conducive environment in which business communication can flourish. In light of this view and also drawing from network theory, IT resource is expected to impact positively on a supplier's communication with its partners in Zimbabwe. Such a relationship has also been supported in prior empirical studies (Dyer \& Singh 1998; Kale et al. 2000; Ali \& Kumar 2011). Accordingly, this study posits five hypotheses. The first is that:

Hypothesis 1: There is a positive relationship between the suppliers' IT resource utilisation and their collaborative communication with business partners in Zimbabwe.

\section{Supplier information technology use and network governance}

IT resource can be viewed as a necessary business infrastructure that facilitates networking between business partners (Kim \& Mahoney 2006). By connecting to a business partner who is also connected to other supply chain partners using IT resources, a network structure is established (Paulraj et al. 2008). Network structure refers to inter-business governance and co-ordination that is characterised by informal social systems in contrast to the use of hierarchical authority (Jones, Hesterly \& Borgatti 1997). These social systems are relational in nature and are characterised by: solidarity, mutuality, flexibility, information exchange and role integrity (Heide \& John 1992; Kaufmann \& Stern 1988; Macneil 1980). In this regard, IT resource plays an important role in activating and translating these relational norms into value-enhancing relational assets (Mohr, Fisher \& Nevin 1996). Thus, through IT resources utilisation, network structure enables the exchange of information among supply chain partners and facilitates the development and maintenance of value-enhancing relational exchanges among supply chain partners (Dyer \& Chu 2003; Poppo \& Zenger 2002; Powell 1990). Similarly, in the context of this study, a supplier's IT resource utilisation is likely to facilitate linkages between business partners in a supply chain. Eventually, a network governance structure that promotes a richer communication among supply chain partners emerges (Jones et al. 1997; Powell 1990; Zaheer \& Bell 2005). Previous studies have also supported a positive relationship between IT resource utilisation and network structure development (Paulraj et al. 2008). Therefore, deducing from the Network theory and empirical evidence, this study posits that:

Hypothesis 2: There is a positive relationship between the suppliers' IT resource utilisation and their network governance with business partners in Zimbabwe. 


\section{Supplier collaborative communication and network governance}

Inter-business long-term orientation has been increasingly recognised as an important factor driving business competitiveness. The reasoning is that, through a long-term relationship, the supplier will become part of a well-managed chain and will have a lasting effect on the competitiveness of the entire supply chain (Choi \& Hartley 1996; Kotabe et al. 2003).

Hypothesis 3: There is a positive relationship between the suppliers' collaborative communication and their network governance with business partners in Zimbabwe.

\section{Supplier collaborative communication and relationship longevity}

Higher levels of collaborative communication in organisations leads to better co-ordination (Cushman \& King 1989) and effective completion of tasks (Guetzkow 1965), which positively affects the performance of alliance relationships (Mohr \& Nevin 1990; Monczka et al. 1998). Promotions of collaborative communication enables supply chain partners to build stronger relational bonds (De Toni \& Nassimbeni 1999; Kotabe et al. 2003; Mohr et al. 1996; Powell, Koput \& Smith-Doerr 1996). Consequently, supply chain partners are able to focus on knowledge development and exchange and increase investment in relational competencies (Madhok \& Tallman 1998; Cousins \& Menguc 2008). Insofar as these relational competencies are 'socially created,' resulting from on-going collaborative communication among exchange partners (Mohr et al. 1996) and not easily tradable in strategic factor markets (Dierickx \& Cool 1989), they may confer durable strategic advantages for the supply chain partners (Kale et al. 2000; Dyer \& Singh 1998). Thus, collaborative communication between suppliers and their partners in the supply chain provides the strategic context necessary for fostering long-term relationships. To that extent, collaborative communication enables the exchange parties to cultivate relational norms that promote co-operation for mutual gains (Heide \& John 1992; Macneil 1980). Accordingly, this study submits that, suppliers' collaborative communication can be expected to foster long-term relationship between suppliers and their partners in the supply chain. Moreover, a positive relationship between collaborative communication and longterm relationship has also been supported previously in the extant management literature (Chen \& Paulraj 2004; Kotabe et al. 2003). Drawing from the foregoing discussion, this study therefore proposes the following hypothesis:

Hypothesis 4: There is a positive relationship between the suppliers' collaborative communication and their relationship longevity with business partners in Zimbabwe.

\section{Supplier network governance and relationship longevity}

Supplier network structure can be an effective governance mechanism that creates co-operative bonding between suppliers and their partners in the supply chain (Dyer \&
Nobeoka 2000). Consequently, as a result of such co-operative bonding, understandings and conventions involving fair play and good faith develop between suppliers and their business partners (Harland \& Knight, 2001). The development of good faith between supply partners generates trust and relationship commitment, which eventually expedites longterm relationships (Kim \& Mahoney 2006). Moreover, the literature indicates that the development of supplier network structures facilitates the integration of logistics activities in supply chains (Chen \& Paulraj 2004) - a process that strengthens and promotes long-term relationships between suppliers and their business partners (Choi \& Kim 2008). In the context of this study, it is expected that the development of suppliers' network structures will facilitate co-operative bonding, trust and relationship commitment (Chinomona \& Pretorius 2011). As a result of this, long-term relationships between the suppliers and their partners is expected to develop. Accordingly, a positive linkage between the suppliers' network structure development and long-term relationship can be anticipated. Previous research has also supported a positive relationship between suppliers' network structure development and long-term relationships (Paulraj et al. 2008). Based on the above-mentioned discussions, the current study postulates the following hypothesis:

Hypothesis 5: There is a positive relationship between the suppliers' network governance and their relationship longevity with business partners in Zimbabwe.

\section{Research methodology} Sample and data collection

The data for this research were collected from Harare, the largest city in Zimbabwe. The research-sampling frame was the Small to Medium Enterprise Association of Zimbabwe. The database of the small and medium enterprises was obtained from the Ministry of small to medium enterprise development in Zimbabwe. Students from the University of Zimbabwe were recruited to distribute and collect the questionnaires after appointments with target small businesses were made by telephone. Of the total of 180 questionnaires distributed, 162 usable questionnaires were retrieved for the final data analysis, representing a response rate of $90.0 \%$.

\section{Measurement instrument and questionnaire design}

Research scales were operationalised on the basis of previous work. Proper modifications were made in order to fit the current research context and purpose. 'Information technology use' measurement used a six-item scale adapted from Chen and Paulraj (2004). 'Collaborative communication' measurement used a seven-item scale, whilst 'network governance' used a four-item scale measurement, which was adopted from Paulraj et al. (2008). Finally, 'relationship longevity' was measured using a five-item scale, which was adapted from Ganesan (1994). All the measurement items were measured on a five-point Likert-type scale that was anchored by 1 = strongly disagree to $5=$ strongly agree in order to express the degree of agreement. 


\section{Respondent profile}

Table 1 presents the profile of the participants. The profile indicates that almost close to three quarters of the participating small businesses employed less than 50 workers $(73.0 \%)$, whilst more than a quarter had a workforce above 51 employees $(27.0 \%)$. More than half of the participants had less than five years working experience (57.0\%), more than a quarter of the participants had five to ten years working

TABLE 1: Sample demographic characteristics.

\begin{tabular}{|c|c|c|c|}
\hline \multicolumn{2}{|l|}{ Demographic characteristics } & \multirow{2}{*}{$\begin{array}{l}\text { Frequency } \\
99\end{array}$} & \multirow{2}{*}{$\begin{array}{l}\% \\
61.1\end{array}$} \\
\hline Gender & Male & & \\
\hline & Female & 63 & 38.9 \\
\hline Total & & 162 & 100 \\
\hline \multirow[t]{3}{*}{ Age } & $\leqq 30$ & 72 & 44.4 \\
\hline & $31-60$ & 59 & 36.4 \\
\hline & $\geqq 60$ & 31 & 19.2 \\
\hline Total & & 162 & 100 \\
\hline \multirow[t]{2}{*}{ Marital status } & Married & 106 & 65.4 \\
\hline & Single & 56 & 34.6 \\
\hline Total & & 162 & 100 \\
\hline \multirow[t]{3}{*}{ Number of employees } & $\leqq 20$ & 63 & 38.9 \\
\hline & $21-50$ & 55 & 34.0 \\
\hline & $\geqq 51$ & 44 & 27.1 \\
\hline Total & & 162 & 100 \\
\hline \multirow[t]{3}{*}{ Participants working experience } & $\leqq 5$ years & 92 & 56.8 \\
\hline & $5-10$ years & 54 & 33.3 \\
\hline & $\geqq 10$ years & 16 & 9.9 \\
\hline Total & & 162 & 100 \\
\hline \multirow[t]{3}{*}{ Monthly salary in US dollar } & $\leqq$ US\$ 200 & 25 & 15.4 \\
\hline & US\$200-US\$ 400 & 91 & 56.2 \\
\hline & $\geqq$ US\$ 400 & 46 & 28.4 \\
\hline Total & & 162 & 100 \\
\hline \multirow[t]{2}{*}{ Industry } & Manufacturing & 88 & 54.3 \\
\hline & Service & 74 & 45.7 \\
\hline Total & & 162 & 100 \\
\hline
\end{tabular}

experience $(33.0 \%)$ and less than a quarter had more than ten years working experience $(10.0 \%)$. Also, more than three quarters of the participating employees earned a monthly salary that was more than US\$200 (84.6\%) and the remainder earned a salary that was less than US\$200 (15.4\%). The article also indicated that the majority of the participants belonged to the manufacturing sector, which occupied $54.3 \%$, whilst the service sector occupied the remainder.

\section{Data analysis}

In this study, a structural equation modeling (SEM) approach, using Smart PLS statistical software (Ringle, Wende \& Will 2005), was used to test the hypotheses in the conceptual research model. Smart PLS is suitable for a small sample size and does not require normal distribution of the manifest variables (Chin, 1998; Chin \& Newsted 1999). Since the current study sample size was relatively small (162), Smart PLS was found to be more appropriate and befitting of the purpose. As recommended by Anderson and Gerbing (1988), a two-stage procedure to hypothesis testing using SEM was utilised in this study. Measurement model assessment was performed first by examining the convergent and discriminant validity of items and constructs respectively, before the testing of the hypothesised causal relationship between the research variables in the structural model.

\section{Measurement model}

To ensure convergent validity, the researcher checked if items were loaded on their respective (a priori) constructs with loadings greater than 0.600 , whilst discriminant validity was checked by ensuring that there were no significant inter-research variable cross-loadings (Chin 1998). As can be seen in Table 2, all items except for ITR4 and CC6,

TABLE 2: Accuracy analysis statistics.

\begin{tabular}{|c|c|c|c|c|c|c|c|c|}
\hline \multicolumn{2}{|c|}{ Research construct } & \multirow{2}{*}{$\begin{array}{l}\text { LV index value } \\
3.993\end{array}$} & \multirow{2}{*}{$\frac{R^{2} \text { value }}{0.000}$} & \multirow{2}{*}{$\begin{array}{l}\text { Cronbach's } \alpha \text { value } \\
0.806\end{array}$} & \multirow{2}{*}{$\begin{array}{l}\text { C.R. value } \\
0.861\end{array}$} & \multirow{2}{*}{$\begin{array}{l}\text { AVE value } \\
0.510\end{array}$} & \multirow{2}{*}{$\begin{array}{l}\text { Communality } \\
0.510\end{array}$} & \multirow{2}{*}{$\begin{array}{l}\text { Factor loading } \\
0.767\end{array}$} \\
\hline ITR & ITR 1 & & & & & & & \\
\hline & ITR 2 & & & & & & & 0.698 \\
\hline & ITR 3 & & & & & & & 0.575 \\
\hline & ITR 4 & & & & & & & 0.775 \\
\hline & ITR 5 & & & & & & & 0.739 \\
\hline & ITR 6 & & & & & & & 0.711 \\
\hline \multirow[t]{6}{*}{ CC } & CC 1 & 3.749 & 0.532 & 0.807 & 0.863 & 0.514 & 0.514 & 0.797 \\
\hline & CC 2 & & & & & & & 0.755 \\
\hline & $\mathrm{CC} 3$ & & & & & & & 0.754 \\
\hline & $\mathrm{CC} 4$ & & & & & & & 0.748 \\
\hline & CC 5 & & & & & & & 0.552 \\
\hline & CC 6 & & & & & & & 0.669 \\
\hline \multirow[t]{5}{*}{ NG } & NG 1 & 3.771 & 0.768 & 0.860 & 0.896 & 0.590 & 0.590 & 0.763 \\
\hline & NG 2 & & & & & & & 0.645 \\
\hline & NG 3 & & & & & & & 0.823 \\
\hline & NG 5 & & & & & & & 0.826 \\
\hline & NG 6 & & & & & & & 0.784 \\
\hline \multirow[t]{6}{*}{$\mathrm{RL}$} & RL 1 & 3.871 & 0.737 & 0.872 & 0.903 & 609 & 0.609 & 0.792 \\
\hline & RL 2 & & & & & & & 0.787 \\
\hline & RL 3 & & & & & & & 0.730 \\
\hline & RL 4 & & & & & & & 0.797 \\
\hline & RL 5 & & & & & & & 0.788 \\
\hline & RL 6 & & & & & & & 0.784 \\
\hline
\end{tabular}

ITR, Information technology resource; CC, Collaborative communication; NG, Network governance; RL, Relationship longevity; C.R., Composite reliability; AVE, Average variance reliability; LV, Latent variable.

Note: Scores: 1 = Strongly disagree; 3 = Neutral; 5 = Strongly agree 
which approached 0.600 (0.552 and 0.575 respectively) have loadings greater than 0.600 , with no cross-loadings greater than 0.850 , whilst $t$-statistics derived from bootstrapping (300 re-samples) suggest that all loadings are significant at a probability value $(\mathrm{pb})$ of 0.001 . As such, this confirms that all the measurement items mostly converged well on their respective constructs and therefore are acceptable measures.

According to Chin (1998), research variables should have an average variance extracted (AVE) of more than 0.500 and a composite reliability of more than 0.700 (convergent validity). The inter-construct correlations should be less than the square root of the AVE (discriminant validity). As can be seen in Table 2, all constructs exceed these criteria, with AVE and composite reliability (CR) generally equal to or greater than 0.600 and 0.800 respectively, and the square root of the AVE being at least 0.710 greater than the inter-construct

TABLE 3: Correlations between constructs.

\begin{tabular}{lllll}
\hline Research constructs & ITR & CC & NG & RL \\
\hline Information technology resource (ITR) & 1.000 & - & - & - \\
Collaborative communication (CC) & 0.629 & 1.000 & - & - \\
Network governance (NG) & 0.670 & 0.708 & 1.000 & - \\
Relationship longevity (RL) & 0.585 & 0.704 & 0.709 & 1.000 \\
\hline
\end{tabular}

ITR, Information technology resource; CC, Collaborative communication; NG, Network governance; RL, Relationship longevity. correlations (Table 3). These results confirm the existence of discriminant validity of the measurements used in this study.

\section{Structural model}

Figure 2 and Table 4 present the current study's results of the PLS analysis. The standardised path coefficients were expected to be at least 0.200 and preferably greater than 0.300 (Chin 1998). Bootstrapping (300 re-samples) was utilised to assess the reliability of each coefficient. The results provide support for all the five hypotheses. All other path coefficients were above 0.2 and significant (pb 0.001). As indicated in Figure 2 and Table 4, the path coefficients are 0.729, 0.324, $0.611,0.226$ and 0.659 for Hypothesis 1, Hypothesis 2, Hypothesis 3, Hypothesis 4 and Hypothesis 5 respectively.

Table 4 provides the $t$-statistics for the hypothesised relationships. The minimum $t$-statistic is 13.020 and therefore exceeds the recommended threshold of 2. This further confirms the statistical significance of the posited relationships and therefore all the hypotheses are supported.

Overall, $R^{2}$ for logistics integration (LI) and small and medium enterprise performance (SMEP) in Figure 2, indicate that the research model explains more than $51.0 \%$ of the variance in the endogenous variables. Following the formulae provided

TABLE 4: Results of structural equation model analysis.

\begin{tabular}{|c|c|c|c|c|}
\hline Proposed hypothesis relationship & Hypothesis $(\mathrm{H})$ & Path coefficients & $t$-statistics & Rejected or supported \\
\hline Information technology resource (ITR) $\rightarrow$ Collaborative communication (CC) & $\mathrm{H} 1$ & 0.729 & 29.081 & Supported \\
\hline Information technology resource (ITR) $\rightarrow$ Network governance (NG) & $\mathrm{H} 2$ & 0.324 & 29.336 & Supported \\
\hline Collaborative communication (CC) $\rightarrow$ Network governance (NG) & $\mathrm{H} 3$ & 0.611 & 14.388 & Supported \\
\hline Collaborative communication (CC) $\rightarrow$ Relationship longevity (RL) & $\mathrm{H} 4$ & 0.226 & 14.586 & Supported \\
\hline Network governance (NG) $\rightarrow$ Relationship longevity (RL) & $\mathrm{H} 5$ & 0.659 & 13.020 & Supported \\
\hline
\end{tabular}

Network governance (NG) $\rightarrow$ Relationship longevity (RL)

ITR, Information technology resource; CC, Collaborative communication; NG, Network governance; RL, Relationship longevity.

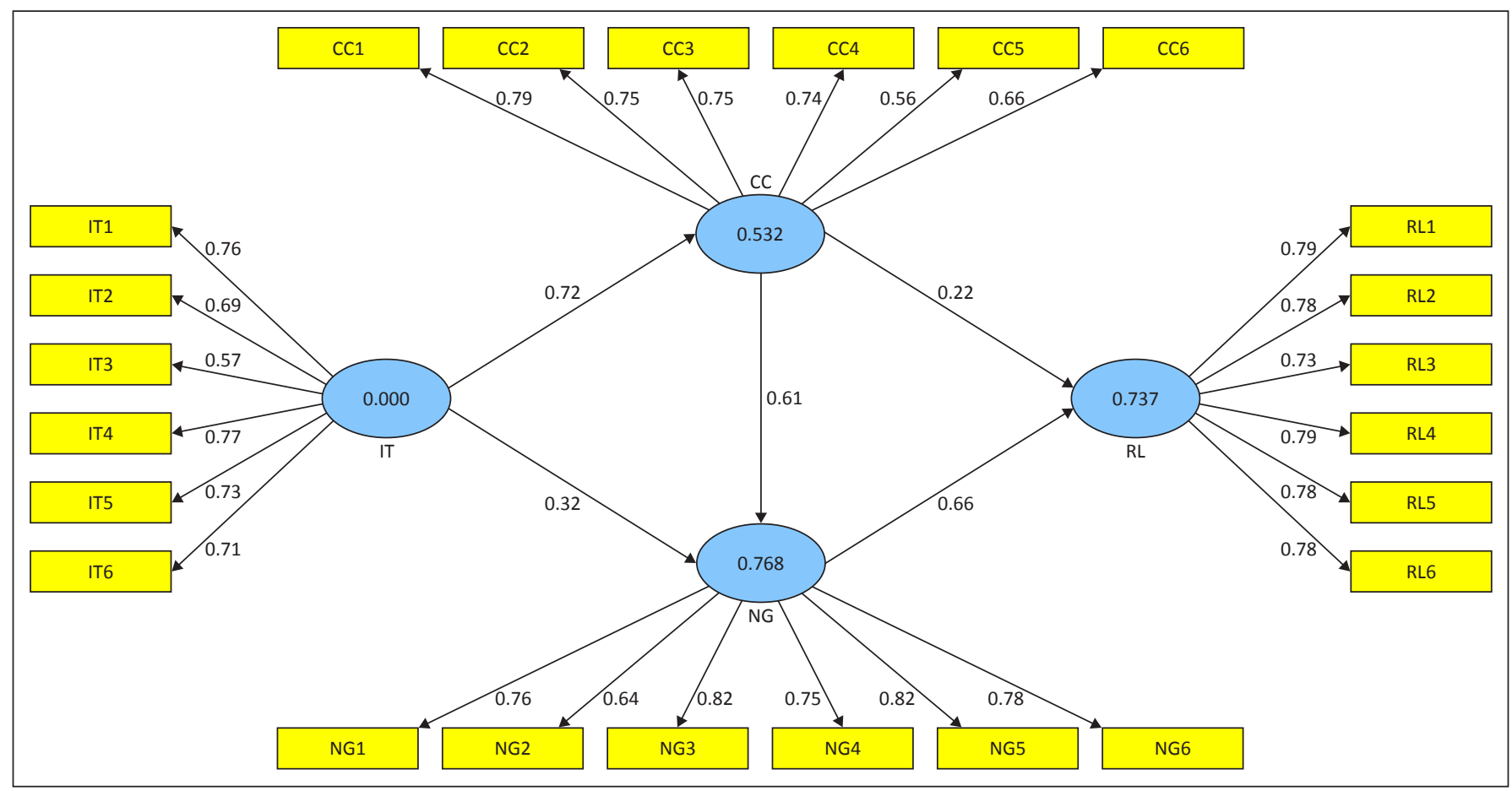

IT, Information technology; CC, Collaborative communication; NG, Network governance; RL, Relationship longevity

FIGURE 2: Measurement and structural model results. 
by Tenenhaus, Vinzi, Chatelin and Lauro (2005), the global goodness-of-fit (GoF) statistic for the research model was calculated and is 0.38 , which exceeds the threshold of GoF $>0.36$ suggested by Wetzels, Odekerken-Schröder and Van Oppen (2009). Thus, this study concludes that the research model has a good overall fit.

\section{Discussion and conclusion}

The purpose of this study was to investigate the fostering role of small and medium enterprise (SME) information technology use on collaborative communication, network governance and relationship longevity. In particular, five hypotheses were postulated. To test the proposed hypotheses, data were collected from SME employees in Zimbabwe. The empirical results supported all the posited research hypotheses in a significant way.

It is important to note about the study findings that the SME information technology has stronger effects on collaborative communication (0.729) than on network governance (0.324). However, network governance strongly influences relationship longevity (0.659) more than SME collaborative communication (0.226). Notably too, the relationship between collaborative communication and network governance is robust (0.611). By implication, this finding indicates that collaborative communication can have a strong influence on relationship longevity via network governance. Perhaps this could be due to the fact that collaborative communication is likely to be more effective between business partners when they are networked and that governance structures are pronounced (Lai et al. 2010).

\section{Implications of the study}

The ever-increasing importance of the SME sector in Zimbabwe cannot be over-emphasised. In particular, contribution to employment generation and economic growth among others has often been cited in the empirical literature (Chinomona et al. 2010; Chinomona \& Pretorius 2011). This article is an attempt to undertake research in an oftenneglected context, but important sector of the Zimbabwean economy. Therefore, the findings of this empirical study are expected to provide fruitful implications to both practitioners and academics.

On the academic side, this article makes a significant contribution to literature by systematically exploring the impact of information technology resources on collaborative communication, network governance and business relationship longevity within the SME context. Overall, the current study findings provide tentative support to the proposition that information technology resources, collaborative communication and network governance should be recognised as significant antecedents for improved relationship longevity between suppliers and their buyers in the SME setting.

On the practitioners' side, the important influential role of information technology resources on relationship longevity in Zimbabwe's SME sector is highlighted. This article therefore submits that SME owners and their managers can benefit from the implications of these findings. For instance, given robust relationship between network governance and relationship longevity (0.659), collaborative communication and network governance (0.611), and IT resource and collaborative communication (0.729), managers in the SME sector and SME owners ought to pay attention to both collaborative communication and network governance. Such endeavours tend to optimise the IT resources impact on their relationship longevity with their business counterparts.

The general observation and conclusion drawn from these findings is that IT use has a positive and significant influence on collaborative communication, network governance and relationship longevity in the SME context - which by and large supports some of the previous research findings in the large business environment (Holmen \& Pedersen 2010; Paulraj et al. 2008; Chen \& Paulraj 2004; Cousins, Lawson \& Squire 2008; Vijayasarathy 2004; Prajogo \& Olhager 2012).

\section{Limitations and future research}

Despite the usefulness of this article, the research has its limitations. First and most significantly, the present research is conducted from the perspective of SME suppliers only. Perhaps if data is collected from both the SME suppliers and their buyers, and a comparative study is done, insightful findings about the impact of IT resources on collaborative communication, network governance and relationship longevity might be revealed. Second, the current study was limited to SMEs in Zimbabwe. Subsequent research should contemplate replicating this study in other developing countries for result comparisons. Finally, further research could also investigate the effects of IT resources on business performance, as the outcome is variable in the context of the SME sector. Such researches might potentially expand the understanding of the impact of IT resources on collaborative communication, network governance, relationship longevity and eventually business performance. These suggested future avenues of study stand to immensely contribute new knowledge to the existing body of SME-management literature, a context that is often neglected by researchers in developing countries (Chinomona \& Pretorius 2011; Chinomona 2012).

\section{Acknowledgements Competing interests}

The author declares that he has no financial or personal relationship(s) that may have inappropriately influenced him in writing this article.

\section{References}

Ali, J. \& Kumar, S., 2011, 'Information and Communication Technologies (ICTs) and Farmers Decision-making across the Agricultural Supply Chain', International Journal of Information Management 31(2), 149-159. http://dx.doi.org/10.1016/j. ijinfomgt.2010.07.008

Anderson, J.C. \& Gerbing, D.W., 1988, 'Structural equation modelling in practice: A review and recommended two-step approach', Psychological Bulletin 103(2), 411-423. http://dx.doi.org/10.1037/0033-2909.103.3.411 
Aviv, Y., 2001, 'The effect of collaborative forecasting on supply chain performance', Management Science 47(10), 1326-1343. http://dx.doi.org/10.1287/mnsc.47. Management Scie

Barkema, H.G. \& Vermeulen, F., 1997, 'What differences in the cultural backgrounds of partners are detrimental for international joint ventures?, Journal International Business Studies 27, 845-64. http://dx.doi.org/10.1057/palgrave.jibs.8490122

Brady, M., Saren, M. \& Tzokas, N., 2002, 'Integrating information technology into marketing practice - The IT reality of contemporary marketing practice', Journal of Marketing Management 18(5/6), 555-577. http://dx.doi.org/10.1362/0267257022683703

Brodie, R. J., Winklhofer, H., Coviello, N.E. \& Johnston, W.J., 2007, 'Is e-marketing coming of age? An examination of the penetration of e-marketing and firm performance' Journal of Interactive Marketing 21(1), 2-21. http://dx.doi.org/10.1002/dir.20071

Cannon, J.P., Achrol, R.S. \& Gundlach, G.T., 2000, 'Contracts, norms, and plural form governance', Journal of the Academy of Marketing Science 28(2), 180-194. http:// dx.doi.org/10.1177/0092070300282001

Carr, A.S. \& Pearson, J.N., 1999, 'Strategically managed buyer-seller relationships and performance outcomes', Journal of Operations Management 17(5), 497-519. http:// dx.doi.org/10.1016/S0272-6963(99)00007-8

Chen, I.J. \& Paulraj, A., 2004, 'Towards a theory of supply chain management: The constructs and measurement', Journal of Operations Management 22(2), 119-150. http://dx.doi.org/10.1016/j.jom.2003.12.007

Chin, W.W. \& Newsted, P.R., 1999, 'Structural equation modeling analysis with small samples using partial least squares,' in Statistical Strategies for Small Sample Research, Rick Hoyle (ed.), Sage Publications, Thousand Oaks, CA, pp. 307-341.

Chin, W.W., 1998, 'Issues and opinion on structural equation modelling', MIS Quarterly 22(1), 7-16.

Chinomona, R., 2012, 'The influence of dealers' referent power and legitimate power in Guanxi distribution networks: The case of Taiwan's SME firms', African Journa of Business Management 6(37), 10125-10137

Chinomona, R., Lin, J., Wang, M. \& Cheng, J., 2010, 'Soft power and desirable relationship outcomes in Zimbabwe distribution channels', African Journal of Business 11(2), 20-55. http://dx.doi.org/10.5897/AJBM11.1494

Chinomona, R. \& Pretorius, M., 2011, 'SME manufacturers' cooperation and dependence on major dealers' expert power in distribution channels', South African Journal of Economics and Management Sciences 12 (2), 170-186.

Choi, T.Y. \& Hartley, J.L., 1996, 'An exploration of supplier selection practices across the supply chain', Journal of Operations Management 14(4), 333-343. http://dx.doi. supply chain', Journal of Operations Man
org $10.1016 /$ S0272-6963(96)00091-5

Choi, T.Y \& Wu, Z., 2009, 'Taking the leap from dyads to triads: Buyer-supplier relationships in supply networks', Journal of Purchasing and Supply Management 15, 263-266. http://dx.doi.org/10.1016/j.pursup.2009.08.003

Choi, T.Y. \& Kim, Y., 2008, 'Structural embeddedness and supplier management: A network perspective', Journal of Supply Chain Management 44(4), 5-13. http:// dx.doi.org/10.1111/j.1745-493X.2008.00069.x

Christiaanse, E. \& Kumar, K., 2000, 'ICT-enabled coordination of dynamic supply webs', International Journal of Physical Distribution and Logistics Management 30(3/4), 268-285. http://dx.doi.org/10.1108/09600030010326019

Cousins, P.D. \& Menguc, B., 2006, 'The implications of socialization and integration in supply chain management', Journal of Operations Management 24(5), 604-620. http://dx.doi.org/10.1016/j.jom.2005.09.001

Cousins, P.D., Lawson, B. \& Squire, B., 2008, 'Performance measurement in strategic buyer-supplier relationships', International Journal of Operations and Production Management 28(3), 238-250. http://dx.doi.org/10.1108/01443570810856170

Croom, S.R., 2001, 'The dyadic capabilities concept: Examining the processes of key supplier involvement in collaborative product development', European Journal
of Purchasing and Supply Management 7(1), 29-37. http://dx.doi.org/10.1016/ of Purchasing and Supply
S0969-7012(00)00019-8

Crowston, K. \& Myers, M.D., 2004, 'Information technology and the transformation of industries: Three research perspectives', The Journal of Strategic Information of industries: Three research perspectives', The Journal of Strategic
Systems 13(1), 5-28. http://dx.doi.org/10.1016/j.jsis.2004.02.001

Cushman, D.P. \& King, S.S., 1989, 'Communication knowledge and ethics: A twentieth century perspective', in S.S. Kind (eds.), Human communication as a field of study: Selected contemporary views, State University of New York Press, Albany, NY.

De Toni, A. \& Nassimbeni, G., 1999, 'Buyer-supplier operational practices, sourcing policies and plant performance: Result of an empirical research', International Journal of Production Research 37(3), 597-619. http://dx.doi.org/10.1080/002075499191698

Dierickx, I. \& Cool, K., 1989, 'Asset stock accumulation and sustainability of competitive advantage', Management Science 35(12), 1504-1513. http://dx.doi.org/10.1287/
mnsc.35.12.1504

Dyer, J.H. \& Chu, W., 2003, 'The role of trustworthiness in reducing transaction costs and improving performance: Empirical evidence from the United States, Japan, and improving performance: Empirical evidence from the United States, Japan, and Korea', Organ

Dyer, J. \& Nobeoka, K., 2000, 'Creating and managing a high-performance knowledge - sharing network: The Toyota case', Strategic Management Journal 21(3), 345-67.
http://dx.doi.org/10.1002/(SICI)1097-0266(200003)21:3<345::AID-SMJ96>3.0.CO;2-N

Dyer, J.H. \& Singh, H., 1998, 'The relational view: Cooperative strategy and sources of inter-organizational competitive advantage', Academy of Management Review 24(4), 660-679.

Fisher, A.C., 2000, 'Investment under uncertainty and option value in environmental economics', Resource and Energy Economics 22, 197-204. http://dx.doi.org/ 10.1016/S0928-7655(00)00025-7

Galt, J.D.A. \& Dale, B.G., 1991, 'Supplier development: A British case study', International Journal of Purchasing and Materials Management 27(1), 19-24.
Ganesan, S., 1994, 'Determinants of long-term orientation in buyer-seller relationships', The Journal of Marketing, 58 (2), 1-19. http://dx.doi.org/10.2307/1252265

Grover, V. \& Malhotra, M., 1997, 'Business process re-engineering: A tutorial on the concept, evolution, method, technology and application', Journal of Operation Management 15, 192-213. http://dx.doi.org/10.1016/S0272-6963(96)00104-0

Guetzkow, H., 1965, Communication in organization. Handbook of Organizations, Rand McNally, Chicago.

Heide, J.B. \& John, G., 1992, 'Do norms matter in marketing relationships?', Journal of Marketing 56(2), 32-44. http://dx.doi.org/10.2307/1252040

Heide, J.B. \& John, C., 1990, 'Alliances in industrial purchasing: The determinants of joint action in buyer-supplier relationships', Journal of Marketing Research 27(1), 24-36. http://dx.doi.org/10.2307/3172548

Jones, C., Hesterly, W. \& Borgatti, S., 1997, 'A general theory of network governance: Exchange conditions and social mechanisms', Academy of Management Review 22(4), 911-945.

Kale, P., Singh, H. \& Perlmutter, D., 2000, 'Learning and protection of proprietary assets in strategic alliances: Building relational capital', Strategic Management Journal 21, 217-237. http://dx.doi.org/10.1002/(SICI)1097-0266(200003)21:3<217::AIDSMJ95>3.0.CO;2-Y

Kaufmann, P.J. \& Stern, L.W., 1988, 'Relational exchange norms, perceptions of unfairness, and retained hostility in commercial litigation', Journal of Conflict Resolution 32, 534-552. http://dx.doi.org/10.1177/0022002788032003007

Kim, K., 2001, 'On the effects of customer conditions on distributor commitment and supplier commitment in industrial channels of distribution', Journal of Business Research, 51, 87-99. http://dx.doi.org/10.1016/S0148-2963(99)00059-4

Kim, N. \& Jae, H.P., 2007, 'Utilization of new technologies: Organizational adaptation to business environments', Journal of the Academy of Marketing Science 35(2), 259-269. http://dx.doi.org/10.1007/s11747-007-0032-6

Kim, S.M. \& Mahoney, J.T., 2006, 'Mutual commitment to support exchange: Relationspecific IT system as a substitute for managerial hierarchy', Strategic Management Journal 27, 401-423. http://dx.doi.org/10.1002/smj.527

Kotabe, M., Martin, X. \& Domoto, H., 2003, 'Gaining from vertical partnerships: Knowledge transfer, relationship duration, and supplier performance improvement in the U.S. and Japanese automotive industries', Strategic Management Journal 24, 293-316. http://dx.doi.org/10.1002/smj.297

Krause, D.R., 1999, 'The antecedents of buying firms' efforts to improve suppliers', Journal of Operations Management, 17(2), 205-224. http://dx.doi.org/10.1016/ S0272-6963(98)00038-2

Krause, D.R. \& Ellram, L.M., 1997, 'Critical elements of supplier development', European Journal of Purchasing and Supply Management 3(1), 21-31. http://dx.doi.org/ 10.1016/S0969-7012(96)00003-2

Krause, D.R., Pagell, M. \& Curkovic, S., 2001, 'Toward a measure of competitive priorities for purchasing', Journal of Operations Management 19, 497-512. http:// dx.doi.org/10.1016/S0272-6963(01)00047-X

Lai, K., Wong, C.W. \& Cheng, T., 2010, 'Bundling digitized logistics activities and its performance implications', Industrial Marketing Management 39(2), 273-286. $\mathrm{http}: / / \mathrm{dx}$.doi.org/10.1016/j.indmarman.2008.08.002

Lee, C.W., Kwon, I.G. \& Severance, D., 2007, 'Relationship between supply chain performance and degree of linkage among supplier, internal integration, and customer', Supply Chain Management: An International Journal 12(6), 444-452.

Lorentz, H. \& Ghauri, P.N., 2010, 'Demand supply network opportunity development processes in emerging markets: Positioning for strategy realization in Russia', Industrial Marketing Management, 39(2), 240-51. http://dx.doi.org/10.1016/j. indmarman.2008.08.005

Harland, C.M. \& Knight, L.A., 2001, 'Supply network strategy: Role and competence requirements', International Journal of Operations and Production Management 21(4), 467-489. http://dx.doi.org/10.1108/01443570110381381

Helper, S.R., 1991, 'How much has really changed between US automakers and their suppliers', Sloan Management Review, 32(4), 15-28.

Helper, S.R. \& Sako, M., 1995, 'Supplier relations in Japan and the US: Are they converging?', Sloan Management Review 36(3), 77-82.

Holland, C.P., Lockett, A.G. \& Blackman, I.D., 1994, 'Planning for electronic data interchange', Strategic Management Journal 13, 539-550. http://dx.doi.org/ 10.1002/smj.4250130706

Holland, C.P., 1995, 'Cooperative supply chain management: The impact of interorganizational information systems', Journal of Strategic Information Systems 4 (2), 117-133. http://dx.doi.org/10.1016/0963-8687(95)80020-Q

Holmen, E. \& Pedersen, A.C., 2010, 'How do suppliers strategise in relation to a customer's supply network initiative?', Journal of Purchasing and Supply Management 16, 264-278. http://dx.doi.org/10.1016/j.pursup.2010.08.004

Lambert, D.M. \& Cooper, M.C., 2000, 'Issues in supply chain management', Industrial Marketing Management, 29, 65-83. http://dx.doi.org/10.1016/S0019-8501(99) 00113-3

Ma, X., Yao, X. \& Xi, Y., 2009, 'How do interorganizational and interpersonal networks affect a firm's strategic adaptive capability in a transition economy?', Journal of Business Research, 62(11), 1087-1095. http://dx.doi.org/10.1016/j.jbusres.2008.09.008

Madhok, A. \& Tallman, S.B., 1998, 'Resources, transactions and rents: Managing value through interfirm collaborative relationships', Organization Science 9(3), 326-339. http://dx.doi.org/10.1287/orsc.9.3.326

Macneil, I.R., 1980, The New Social Contract, Yale University Press, New Haven, CT.

Melville, N., Kraemer, K. \& Gurbaxani, V., 2004, 'Information technology and organizational performance: An integrative model of IT business value', MIS Quarterly 28(2), 
Mentzer, J.T. \& Konrad, B.P., 1991, 'An efficiency/effectiveness approach to logistics performance analysis', Journal of Business Logistics 21(1), 33-62.

Merrilees, B., Rundle-Thiele, S. \& Lye, A., 2011, 'Marketing capabilities: Antecedents and implications for B2B SME performance', Industrial Marketing Management 40, 20, 368-375. http://dx.doi.org/10.1016/j.indmarman.2010.08.005

Mohr, J. \& Nevin, J.R., 1990, 'Communication strategies in marketing channels: A theoretical perspective', Journal of Marketing 54(4), 36-51. http://dx.doi.org/ $10.2307 / 1251758$

Mohr, J., Fisher, R.J. \& Nevin, J.R., 1996, 'Collaborative communication in interfirm relationships: Moderating effects of integration and control', Journal of Marketing 60(3), 103-115. http://dx.doi.org/10.2307/1251844

Modi, S.B. \& Mabert, V.A., 2007, 'Supplier development: Improving supplier performance through knowledge transfers', Journal of Operations Management 25(1), 42-64. http://dx.doi.org/10.1016/j.jom.2006.02.001

Monczka, R.M., Trent, R.J. \& Handfield, R.B., 2002, Purchasing and Supply Management 2nd edn., South-Western, Mason, $\mathrm{OH}$.

Monczka, R., Petersen, K., Handfield, R. \& Ragatz, G., 1998, 'Success factors in strategic supplier alliances: The buying company perspective', Decision Sciences Journa 29(3), 553-577. http://dx.doi.org/10.1111/j.1540-5915.1998.tb01354.x

Moorman, C., Zaltman, G. \& Deshpande, R., 1992, 'Relationships between providers and users of market research: The dynamics of trust within and between organizations', Journal of Marketing Research, 29 (3), 314-328. http://dx.doi.org/10.2307/3172742

Oz, E., 2005, 'Information technology productivity: In search of a definite observation' Information \& Management 42, 789-798. http://dx.doi.org/10.1016/j.im.2004. 08.003

Otley, D. \& Pollanen, R.M., 2000, 'Budgetary criteria in performance evaluation: A critical appraisal using new evidence', Account, Organ, Soc 25, 483-96. http:// dx.doi.org/10.1016/S0361-3682(98)00031-2

Palmer, J.W. \& Griffith, D., 1998, An emerging web site design model for marketing, Communications of the ACM, 41(3), 44-51. http://dx.doi.org/10.1145/272287. 272296

Paulraj, A. Lado, A.A. \& Chen, I.J, 2008, Inter-organizational communication as a relational competency: Antecedents and performance outcomes in collaborative buyer-supplier relationships, Journal of Operations Management 26(1), 45-64. buyer-supplier relationships, Journal of Operation.
http://dx.doi.org/10.1016/j.jom.2007.04.001

Poppo, L. \& Zenger, T.R., 2002, 'Do formal contracts and relational governance act as substitutes or complements?', Strategic Management Journal 23(8), 707-725. http://dx.doi.org/10.1002/smj.249

Powell, W.W., Koput, K.W. \& Smith-Doerr, L., 1996, 'Inter-organizational collaboration and the locus of innovation: Networks of learning in biotechnology', Administrative Science Quarterly 15(1), 88-102.

Powell, T.C. \& Dent-Micallef, A., 1997, 'Information technology as competitive advantage: The role of human, business, and technology resources', Strategic Management Journal 18(5), 375-405. http://dx.doi.org/10.1002/(SICI)1097-0266(199705)18: 5<375::AID-SMJ876>3.0.CO:2-7

Powell, W.W., 1990, 'Neither market nor hierarchy: Network forms of organization' in B.M. Staw \& L.L. Cummings (eds.), Research in Organizational Behavior, 12. JA Press, Greenwich, CT, pp. 295-336.

Prajogo, D. \& Olhager, J., 2012, 'Supply Chain Integration and Performance: The effects of long-term relationships, information technology and sharing, and logistics integration', International Journal of Production Economics 135, 514-522. http:// dx.doi.org/10.1016/j.ijpe.2011.09.001
Prahinski, C. \& Benton, W.C., 2004, 'Supplier evaluations: Communication strategies to improve supplier performance', Journal of Operations Management 22, 39-62. http://dx.doi.org/10.1016/j.jom.2003.12.005

Rapp, A., Rapp, T. \& Schillewaert, N., 2008, 'An empirical analysis of e-service implementation: Antecedents and the resulting value creation', Journal of Services Marketing 22(1), 24-36. http://dx.doi.org/10.1108/08876040810851932

Reinsch, N.L., 2001, 'Business performance: Communication is a compound, not a mixture', Vital Speeches of the Day 67(6), 172-174.

Ringle, C.M., Wende, S. \& Will, A., 2005, SmartPLS (Version 2.0[beta ])', University of Hamburg, Hamburg, viewed 10 November 2013, from http://www.smartpls.de

Rivard, S., Raymond, L. \& Verreault, D., 2006, 'Resource-based view and competitive strategy: An integrated model of the contribution of information technology to firm performance', Journal of Strategic Information Systems, 15, 29-50. http:// dx.doi.org/10.1016/j.jsis.2005.06.003

Roseira, C., Brito, C. \& Henneberg, H.C., 2010, Managing interdependencies in supplier networks, Industrial Marketing Management, 39 (6), 925-935. http://dx.doi.org/ 10.1016/j.indmarman.2010.06.012

Streeter, C.L. \& Gillespie, D.F., 1992, 'Social network analysis', Journal of Social Service Research 16(1/2), 201-222.

Su, H. \& Zhang, P., 2006, 'Causal relationships between perceived enjoyment and perceived Ease of Use: An alternative approach', Journal of the Association for Information Systems 7(9), 618-645.

Subramani, M., 2004, 'How do suppliers benefit from information technology use in supply chain relationships?', MIS Quarterly 28(1), 45-73.

Tenenhaus, M., Vinzi, V.E., Chatelin, Y.M. \& Lauro, C., 2005, 'PLS path modeling' Computational Statistics \& Data Analysis 48(1), 159-205. http://dx.doi.org/10.1016/ j.csda.2004.03.005

Trainor, K.J., Rapp, A., Beitelspacher, L.S. \& Schillewaert, N., 2011, Integrating information technology and marketing: 'An examination of the drivers and outcomes of e-Marketing capability', Industrial Marketing Management 40, 162-174. http:// dx.doi.org/10.1016/j.indmarman.2010.05.001

Vijayasarathy, L.R., 2004, 'Predicting consumer intentions to use online shopping: The case for an augmented technology acceptance model', Information and Management 41(6), 747-762. http://dx.doi.org/10.1016/j.im.2003.08.011

Walton, S.V. \& Marucheck, A.S., 1997, 'The relationship between EDI and supplier reliability', International Journal of Purchasing and Materials Management 33(3), 30-35. http://dx.doi.org/10.1111/j.1745-493X.1997.tb00029.x

Wetzels, M., Odekerken-Schröder, G. \& Van Oppen, C., 2009, 'Using PLS path modeling for assessing hierarchical construct models: Guidelines and empirical illustration', Management Information Systems Quarterly, 33(1), 177-195.

White, A., Daniel, E.M. \& Mohdzain, M., 2005, 'The role of emergent information technologies and systems in enabling supply chain agility', International Journal of Information Management 25(5), 396. http://dx.doi.org/10.1016/j.ijinfomgt.2005. 06.009

Zaheer, A. \& Bell, G.G., 2005, 'Benefiting from network position: Firm capabilities, structural holes, and performance', Strategic Management Journal 26(9), 809-825. http://dx.doi.org/10.1002/smj.482

Zhou, K.Z., Yim, C.K. \& Tse, D.T., 2005, 'The effects of strategic orientations on technology and market-based breakthrough innovations', Journal of Marketing 69(2), 42-60. http://dx.doi.org/10.1509/jmkg.69.2.42.60756

Zhao, X., Xie, J. \& Zhang, W.J., 2002, 'The impact of information sharing and ordering co-ordination on supply chain performance', Supply Chain Management $7(1)$ 24-40. http://dx.doi.org/10.1108/13598540210414364 